\title{
DISCOVERY LEARNING (DL) STRATEGY ON STUDENTS READING COMPREHENSION IN REPORT TEXT
}

\author{
Mayang Sari ${ }^{1}$, \\ SMA Negeri 6 Karawang \\ petitepoetic@gmail.com \\ Tryanti R. Abdulrahman ${ }^{2}$, \\ Universitas Islam As-Syafiíyah \\ tryantia.fkip@uia.ac.id
}

\begin{abstract}
This research entitled "Discovery Learning strategy on Grade Eleven Students' Reading Comprehension in Report text at SMA Negeri 6 Karawang" principally aims to investigate whether or not DL strategy significantly affects on Students'Reading Comprehension. Research method used in this research was quasi experimental, quantitative and the design was randomized post-test only control group design.To collect data the writer used instruments in the form of objective, multiple choice 30 question items for sample class out of 60 questions items that have been tried out in IPS class on grade eleven at SMA Negeri 6 Karawang. The scores obtained from the try-out class were used to analyze the validity, reliability, discrimination power and difficulty index of each question items in the instruments.

The sample of this research was grade eleven students in IPS class consisting of 60 students. The students is divided into two classes, 30 students in experimental class thought using DLstrategy and 30 in control class thought without DL strategy that are taken from the population using cluster random technique. The analysis using SPSSbased One Way Anova Formula produced significance (Sig.) value of 0.002, since the significance value was smaller than $(<)$ Alpha 0.05 , H0 is rejected and HAis accepted. It means that DL Strategy has significant effect on students' reading comprehension.
\end{abstract}

The Key Words : DLStrategy, Reading Comprehension, Report text.

\section{Introduction}

English has considered to be the first language in Indonesia. In relation to that Indonesia has been carrying out teaching EFL in almost level of schools, starting to be taught in Elementary school until Collage.

Therefore, people need to learn English well. In learning English, there are four skills which have to be mastered by the learners. They are listening, speaking, reading and writing. Among those English skills, reading plays an important role in our life.Reading as one of the important skills in acquiring a new language functions as a way for the learners to get new information and adding their knowledge. By reading, students can also enrich their vocabulary and develop their grammar. 
In 2013 Curriculum, Noh (2013) defined, "The goal of teaching reading at Senior High School is to enable students to comprehend social functions, generic structures, and language features of the text."'(p.85). For that reason, ideally, Senior High School students are taught to comprehend two kind of text namely functional and monologue text.However, as a fact reveals the avarege of students' National Examination (UN) has taking down from 55,2 in 2016 becoming 50,93 in 2017 or has taking down 4,09 poin. These cases proves that English is considered as a difficult subject for Indonesian students.

According to Rahmi\&Ratmanida (2014) these problems are caused by several factors, there are:Students' lack of background knowledge such as related idea, linguistic elements, and the structure of the text, students are difficult in finding detail information, answer WHquestion, vocabulary, and find out inference information. Strategies that the teacher used in teaching reading is monotonous. These the problems that make report text difficult to comprehend by the students.

Related with some problems above, the teacher need to use an appropriate strategy in teaching reading that could help them to solve their problem.DL strategy is one of strategy that can improve students' reading comprehension.DLwas introduced by Jerome Bruner in 1961 is a popular theory encourage learners to build on past experiences and knowledge, use their intuition, imagination and creativity, and search for new information to discover facts, correlations and new truths.

In accordance with reading activity, there was a research conducted by Mahmoud (2014) study reported the implementation of guided DLstrategy could encourage students' achievement and metacognitive skills. This is shown by the mean score of the experimental class is 56.98 and the mean score of the control class is 48.2 .

Inspired and encourage by the usefulness and benefits of the DLas teaching strategy on reading comprehension discussed above, which have been verified empirically by several researches, the writer would like to conduct the research in the same area in an effort to investigate whether DLis also be effective strategy on grade eleven students' reading comprehension in report text at SMA N 6 Karawang, in the academic year 2017/2018.

\section{Literature Review}

"Reading is an active process in which people extract the ideas, concepts,thoughts or imagines from the pattern of world, set forth on the printed page."(Callahan \& Clark, 1982).

Grabe and Stoller (2002) stated that "Reading comprehension is a compex cognitive process in which a reader decodes a symbols or printed message into sounds." In conclusion, reading comprehension is the process to get ideas, information and author's message in print page involved perceived and understand words relationship.

The indicator of reading comprehension to be meausred for this research according to (Kitao \& Kitao, 1987) in their artictle "Testing Reading Comprehension" in which students are able to understand the content of the text such as identify the goal, generic structure and language features of the text, interpret vocabulary in the text, and infer the main idea of the text. Hood and Soloman (2012) also stated by reading students are able to get information throughly. These are also based on revised Bloom taxonomy by Anderson and Krathwolh (2001) of understanding (C2), and analyzing (C4). 
To achieve the goal of learning process, teacher should use an appropiate strategy. As Chamot (2004) said, "Learning strategy are the conscious thoughts and actions that learners take in order to achieve a learning goal." (p. 14). There are many strategies in teaching English one of the is DL strategy

Bruner (1986) stated that DL strategy can be defined as the learning that takes place when the student is not presented with subject matter in the final form, but rather is required to organize it him self. (as cited in Lefancois, 1986, p.103). Futhermore, according to Joolingen (1999) DL strategy is type of learning strategy where learners constructtheir own knowledge by experimenting with a domain, and inferring rules from the results of these experiments.Similarly,Thorsett (2002) defined DL strategy as a learningsituation in which the principal content of what is to be learned is not given, but must be independently discovered by the learner, making the student becomes anactive participant in his learning.

As mention above, the writer assume that DL strategy is the effective strategy in teaching reading comprehension in which the facts or the contents of the topic are not given by the teacher in the beginning of the lesson directly, but it must be discovered by the learners through observing and experimenting activities.

Then, about report text, it is actually a text that presents, classifies, and describes factual information about people, animals, things, and phenomena. Report text more focuses on general points; for example report about tiger, lion, cat, parrot and others.

\section{Methodhology}

\section{Hypothesis}

To find out whether or not there is significant effect of using DL strategy on Students' Reading Comprehension, the hypothesis formulated as follows:

\section{Null Hypothesis $\left(\mathbf{H}_{0}\right)$}

There is no effect of using DL strategy on Grade Eleven Students' Reading Comprehension at SMA Negeri 6 Karawang.

\section{Alternative Hypothesis $\left(\mathrm{H}_{\mathbf{a}}\right)$}

There is no effect of using DL strategy on Grade Eleven Students' Reading Comprehension at SMA Negeri 6 Karawang.

\section{Research Design}

In this research, the writer used a quasi-experimental method, in which the treatment condition did not allow a strict control. This design of this research was post-test only control group design. The first group namely as experimental group that were taught using DL strategy and another group namely as control group that were taught without using DL strategy. Both group were given post-test.

\section{Participants}


The population of this research consists of 350 students of grade eleven at SMA Negeri 6 Karawang and consisting of 10 classes. To determine sample of this research, the writer used Cluster Random Sampling. The number of students that participated in this research is about 60 students divided into two classes each class consisting of 30 students in as experimental class and control class.

\section{Variables and Measures}

In this research, independent variable is DL strategy. Dependent variable in this research is Reading Comprehension. To measure students'reading comprehension, the writer took score from indicators of reading comprehension, asfollows:

1. The students are able to summarize the main idea of the text.

2. The students are able to explain the question base on the text.

3. The students are able to analyze the generic structure and language features of the text.

4. The students are able to interpret the similar meaning, synonim and antonym of word from the text.

5. The students are able to infer the communicative purpose of the text.

\section{Validity and Reliability}

The indicators of reading comprehension result were developed to be instrument. The instrument was objective test with 60 items. Those items were analyzed its validity using Pearson Product Moment Correlation Coefficient, reliability using Alpha Cronbachformula, difficulty index and discrimination power to obtain good instrument using Microsoft Excel 2010. After the items have been analyzed, the good items that valid, reliable, satisfactory and medium were chosen to obtain good data. The question items were left 30 numbers.

\section{Procedure}

Procedures of the research are:

1. Planning. Planning phase of this research is preparing and arranging the research design to get the research data. Before conducting the research, the writer formulates the hypothesis based on some related theories and lesson plan of teaching listening usingPodcast.

2 Collecting Data. The data were collected by giving post-test to the students in experiment class and controlclass.

3. Data Analysis. The data collected from the sample classes were analyzed by using ANOVA, after the pre-requisite analyses of normality and homogeneity have been fulfilled.

4. Reporting. The research finding is reported and written based on the formal frame of writing.

\section{Result}

Table

ANOVA 


\begin{tabular}{|l|r|r|r|r|r|}
\hline & \multicolumn{1}{|c|}{$\begin{array}{c}\text { Sum of } \\
\text { Squares }\end{array}$} & Df & \multicolumn{1}{c|}{$\begin{array}{c}\text { Mean } \\
\text { Square }\end{array}$} & \multicolumn{1}{c|}{ F } & Sig. \\
\hline Between & 610.815 & 1 & 610.815 & 11.072 & .002 \\
Groups & 1544.652 & 28 & 55.166 & & \\
Within Groups & 29 & & & \\
Total & 2155.467 & 29 & & \\
\hline
\end{tabular}

The calculation showed that the significance effect (sig.) 0.002 is lower than $<0.05$,

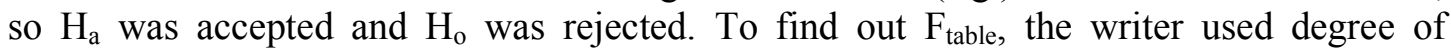

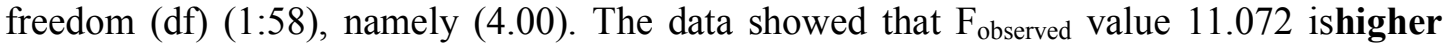
than $>F_{\text {table }}$ 4.00. It means that there is significant effect of $X$ variable (DL strategy) on $Y$ variable (Reading Comprehension).

\section{Discussion}

This research concern with the study about the effect of DL strategy on students' reading comprehension. The findings revealed that there was effect of DL strategy on reading comprehension in report text at SMA Negeri 6 Karawang because the significance (Sig.) score 0.002 is lower than $(<) 0.05$.

The research showed empirically from the theory that is conveyed by NSW (2011): DL strategy is very suitable with the process of understanding report text in which the students are expected to comprehend factual information about people, animal, things, or phenomena in environment.

Another finding in this research is the advantages of DL strategy in which it helps students to understand report text on reading comprehension. This finding is similar to Rahmi and Ratmanida (2014) study that this strategy can be a way to comprehend report text in improving students' reading comprehension.

Moreover, students in this research perceived that they are motivated to learn English particularly reading skill in understanding the report text. This is shown by their enthusiasm during the treatment period using DL strategy. Students are able to analyze the grammatical rule of report text such as generic structure, social function, and language features of the text. It is obviously seen that in line with Mahmoud (2014) study which found the result of students' post-test shown that mean score of the Experimental class is 56.98 and the mean score of control class is 48.2. From this result, it can be concluded that the implementation of guided DL strategy could encourage students' achievement and metacognitive skills.

In addition, the most important one to show that this strategy was effective is the post-test score of the experimental class which is given DL strategy. There was found the mean score of experimental class is 77.4, it is better than score of control class was 66.8 on post-test. The same result also reported by Singaravelu (2012) found mean scores of the students in post-test of control group is 57.43 and mean scores of the students post-test of experimental group is 86.76. this result prove that the participants of the experimental group using DLstrategy performed better as compared to participants of the control group in learning English. 
In this research, the writer concluded that there so many benefits of DL strategy in improving students' reading comprehension, such as enriches students' vocabulary, help the students to findout the information of the text, analyzing the generic structure, social function and language features of the text, make the students more creative,confident, and the last motivated students in improving their English skill.

\section{Conclusion}

The implementation of DL strategy on reading comprehension have done sucessfully. As the result of data analysis of this research, such as normality test, homogeneity test, and ANOVA in the Chapter IV, the researcher concluded that there is an effect of DL strategy on students' reading comprehension. The effect can be seen from the improvement on the students' reading comprehension through on post-test.

According to the research findings, it can be seen that students' reading comprehension obtained by the students who were taught by using DL strategy are higher than students who were not taught by using discovery learning strategy.

In addition, students' response in experimental class are positive toward DL strategy, which help the students to improve their reading comprehension. Students are more active and have critical thinking in learning process. Students also be able to identify the generic structure, social function, and language features of the text while they find out an inference information of the text.

Based on the explanation above, the writer concludes that there is a significant effect of using discovery learning strategy on students' reading comprehension at SMA Negeri 6 Karawang in academic year 2017-2018.It is showed by the analysis of data which explained that the Alternative Hypothesis (Ha) was accepted and the Null Hypothesis (Ho) was rejected.

\section{REFERENCES}

Arikunto, P. D. (2013). Dasar-Dasar Evaluasi Pendidikan. Jakarta: PT Bumi Aksara.

Arikunto, P. D. (2010). Prosedur Penelitian. Jakarta: PT. RINEKA CIPTA.

Bruner, J. (1961). Instructional Design Models and Theories: The Discovery Learning Model. Retrieved from Discovery Learning: https://elearningindustry.com/discoverylearning-model

Bruner, J. (1961). Instructional Design Models and Theories: The Discovery Learning Model. Retrieved from Discovery Learning: https://elearningindustry.com/discoverylearning-model

Discovery-Based Learning in Word Art : Creativity and Collaboration in the Undergraduate Fine Art Class2013Teaching Innovation Project 3

Drs. Achmad Dasuki, M. M. (2014). Pengantar Statistika untuk Penelitian dan Pendidikan. Jakarta. 
Effendy, m. (2015). KEMENTERIAN PENDIDIKAN DAN KEBUDAYAAN. Retrieved from Indeks Integritas Ujian Nasional (IIUN) Tingkat Sekolah:

https://puspendik.kemdikbud.go.id/hasil-un/\#

Eskandari, m., \& Soleimani, h. (2016). The Effect of Collaborative Discovery Learning Using MOODLE on the Learning of Conditional Sentences by Iranian EFL Learners. Theory and Practice in Language Studies, 153-163.

http://file.upi.edu/Direktori/FIP/JUR._PEND._LUAR_SEKOLAH/195404021980112001IHAT_HATIMAH/Pengertian_Pendekatan,_strategi,_metode,_teknik,_taktik_dan.pdf. (n.d.). Retrieved from http://file.upi.edu.com.

Joolingen, W. a. (1999). Cognitive Tools for Discovery Learning. In W. a. Joolingen, Cognitive Tools for Discovery Learning (pp. 225-234). Blackwell Publishing Ltd.

Kitao, K., \& Kitao, S. K. (1996). Testing Reading. Testing Reading .

Leo, S. (2013). A Challenging Book to Practice Teaching in English.Yogyakarta: C.V ANDI OFFSET.

Min, M. (2017, January 2). 20 Pengertian Strategi Menurut Pendapat Para Ahli Terlengkap. Retrieved from http://www.pelajaran.co.id/2017/02/pengertian-strategi-menurut-pendapatpara-ahli-terlengkap.html

NSW2011School A to ZNew South WalesDepartment of Education and Training

Nunan, D. (1991). Language Teaching Methodology. Sidney: PRENTICE HALL.

Pappas, C. (2014, October 8). Instructional Design Models and Theories: The Discovery Learning Model. Retrieved October 8, 2014, from e Learning Industry Web site:

https://elearningindustry.com/discovery-learning-model

sari, n. r., \& Kusumarasdyati. (2014). THE IMPLEMENTATION OF GUIDED DISCOVERY LEARNING TO TEACH READING OF NARRATIVE TEXT TO TENTH GRADERS , 1-6.

Singaravelu, G. (2012). Discovery Learning in English. ERIC Journal , 57-61.

Sugiyono, P. D. (2011). Metode Penelitian Kuantitatif Kualitatif dan R\&D. Bandung: Anggota Ikatan Penerbit Indonesia (IKAPI).

Suryabrata, S. (2012). Metodologi Penelitian. Jakarta: PT RAJA GRAFINDO PERSADA.

The Effects of Discovery Learning on Students' Success and Inquiry Learning Skills2009Eurasian Journal of Education Research 1-20

The Teaching + Learning Lab. (n.d.). Retrieved from http://tll.mit.edu/help/what-strategicteaching

The use of discovery learning strategy in teaching reading report text to senior high school students 2014

Thorsett, P. (2002, May 28). Discovery learning theory. Retrieved May 28, 2013, from Discovery learning theory Web site: http://www.limfabweb.weebly.com 
